\title{
Analisis Kesulitan Mahasiswa Institut Teknologi dan Sains Nahdlatul Ulama Pasuruan pada Mata Kuliah Biologi Umum Materi Sistem Pencernaan Manusia
}

\author{
Sisca Desi Prastyaningtias \\ Pendidikan Biologi, Institut Teknologi dan Sains Nahdlatul Ulama Pasuruan \\ siscadesi@itsnupasuruan.ac.id
}

\begin{abstract}
Learning difficulty students at the Nahdlatul Ulama Institute of Technology and Science Pasuruan in first semester for academic on year 2018/2019 which are marked by midterm scores in general Biology courses for human digestive system meterial that is deficient. Learning Difficulty student can lead to their lack of achievement in this course. This research was conducted to find out the factors of learning difficulty both internal and external by the students and the expectation is to be able to provide further input as an effort to resolve the difficulty learning to improve their learning achievement. This research is a qualitative descriptive study that aims to determine the internal and external factors that induces difficulty student Learning in General Biology courses in human digestive system material. The study used a descriptive design, tests, questionnaires and interviews to receive data. The research subjects are 32 students are from Biology, Mathematics, Physics and Agricultural Product Technology major. Based on the results of the study for the internal factors that cause their difficulty for Learning are study habits and ability material comprehension are still lacking as much as $59.37 \%$, while the external factors are the lack of learning support tools as much as $59.37 \%$ and the condition of the house environment and around it as much as 50\%.
\end{abstract}

Keywords: Biology, learning difficulty student, general biology, human digestive system

This is an open access article distributed under the Creative Commons 4.0 Attribution License, which permits unrestricted use, distribution, and reproduction in any medium, provided the original work is properly cited. $@ 2018$ by author and Universitas Negeri Padang.

\section{PENDAHULUAN}

Institut Teknologi dan Sains Nahdlatul Ulama (ITSNU) Pasuruan merupakan salah satu Perguruan Tinggi yang baru berdiri tahun 2018 yang menghasilkan tenaga kependidikan, teknologi dan desain. Institut ini memiliki beberapa program studi antara lain, Desain, Teknik dan Kependidikan Matematika dan Ilmu Pengetahuan Alam. Pada jurusan kependidikan MIPA terdapat jurusan Pendidikan Matematika, Pendidikan Biologi dan Pendidikan Fisika. Kurikulum ITSNU Pasuruan, khususnya untuk program studi kependidikan MIPA terdapat matakuliah keilmuan dan keterampilan (MKK) yang wajib diambil yaitu Biologi Umum. Mata kuliah ini diajarkan pada semester I dengan bobot 2 SKS.

Tujuan mata kuliah biologi umum adalah agar mahasiswa memahami tentang prinsipprinsip dasar biologi dan wawasan biologi secara menyeluruh serta hubungannya dengan disiplin ilmu lainnya. Secara khusus, mata kuliah biologi umum merupakan materi dasar sebagai prasyarat untuk mengambil mata kuliah lain semester tingkat atas. Oleh karena itu, materi tersebut perlu mendapat perhatian yang besar karena berkaitan dengan masalah penguasaan materi, pemilihan metode pembelajaran yang cocok, penetapan strategi, dan teknik pembelajaran yang sesuai sebagai bekal mahasiswa untuk perkuliahan selanjutnya. Hal tersebut sesuai dengan yang dikemukakan oleh Marsita, dkk (2010), bahwa konsep yang menjadi suatu prasyarat untuk mempelajari konsep selanjutnya sangat penting untuk dipahami dan dikuasai.

Materi sistem pencernaan pada manusia adalah materi biologi yang mempelajari beberapa peristiwa yang berkaitan dengan manusia itu sendiri seperti proses pencernaan maupun kelainan atau penyakit yang dapat terjadi pada sistem pencernaan. Dilihat dari obyek dan sifat materinya, sistem pencernaan terdapat di dalam tubuh yang tidak dapat teramati secara langsung sehingga siswa relatif sulit untuk membayangkannya.

Kesulitan belajar dapat mengakibatkan individu yang bersangkutan menjadi sulit melakukan kegiatan belajar secara efektif. Fenomena kesulitan belajar siswa umumnya tampak jelas dari menurunnya kinerja akademik atau prestasi belajarnya. Selain itu, kesulitan belajar juga dapat dibuktikan dengan munculnya 
kelainan perilaku siswa (Ristiyani dan Bahriah, 2016). Kesulitan belajar yang sering dialami mahasiswa biasanya terjadi karena mereka cenderung tidak memiliki ketertarikan untuk mengikuti proses pembelajaran. Hal ini mengakibatkan siswa mengalami kesulitan belajar dikelas. Selain faktor kesulitan belajar yang dihadapi siswa terdapat faktor lain seperti faktor internal dan eksternal. Faktor internal merupakan faktor yang timbul dari dalam diri seseorang, sedangkan faktor eksternal merupa kan faktor yang timbul dari lingkungan luar seperti faktor orang tua, lingkungan sekolah, dan masyarakat (Martini, 2014). Penelitian ini bertujuan untuk mengetahui faktor-faktor internal dan eksternal penyebab kesulitan belajar mata kuliah Biologi Umum materi sistem pencernaan manusia pada mahasiswa Institut Teknologi dan Sains Nahdlatul Ulama (ITSNU) Pasuruan

\section{METODE PENELITIAN}

Penelitian dilakukan di Institut Teknologi dan Sains Nahdlatul Ulama (ITSNU) Pasuruan Jl. Raya Warung Dowo Komplek Perkantoran PCNU Kabupaten Pasuruan, Jawa Timur yang dilaksanakan pada tanggal 12-16 November 2018. Objek penelitian adalah seluruh mahasiswa mahasiswa semester 1 tahun ajaran 2018/2019 yang memprogram matakuliah Biologi Umum yaitu program studi Pendidikan Biologi sebanyak 13 orang, Pendidikan Matematika sebanyak 6 orang dan Teknik Hasil Pertanian sebanyak 7 orang, dan Pendidikan Fisika 6 orang sehingga total sebanyak 32 orang.

Penelitian ini menggunakan metode penelitian deskriptif dengan menyelidiki responden mahasiswa mengenai tingkat kesulitan belajar beserta faktor faktor penyebab kesulitan yang dialami mahasiswa.

Teknik pengumpulan data dalam peneliti an ini terdiri dari pengisian angket, wawancara dan penilaian dari tes materi sistem pencernaan pada manusia.

Teknik pengumpulan data dengan meng gunakan angket yang dibuat dengan meng gunakan skala likert dengan kategori (SS) sangat setuju, (S) setuju, (TS) tidak setuju dan (STS) sangat tidak setuju.

Data hasil angket mahasiswa diukur dengan menggunakan skala Likert dan data yang diperoleh berupa data kualitatif. Data kualitatif kemudian diubah menjadi data kuantitatif.
Setelah dirubah menjadi data kuantitatif. Kemudian dilakukan perhitungan tiap butir soal menggunakan rumus (Lestari dan Yudhanegara, 2015) sebagai berikut:

$$
\mathrm{P}=\frac{\mathrm{F}}{\mathrm{N}} \times 100 \%
$$

Keterangan:

$\mathrm{P}=$ Presentasi Jawaban

$\mathrm{F}=$ Frekuensi Jawaban

$\mathrm{N}=$ Jumlah Responden

Adapun interpretasi yang digunakan untuk menentukan kategori pada tiap indikator penyebab kesulitan belajar mahasiswa sebagai berikut (Riduwan, 2014):

Angka 0\% $-20 \%=$ Pengaruh sangat kuat Angka 21\%- $40 \%=$ Pengaruh kuat Angka 41\% - 60\% = Cukup berpengaruh Angka $61 \%-80 \%=$ Pengaruh lemah Angka 81\% - 100\% = Pengaruh sangat lemah

\section{HASIL DAN PEMBAHASAN}

Aspek kesulitan mahasiswa dalam mema hami konsep sistem pencernaan pada manusia dapat dilihat dari jawaban hasil tes berupa pemahaman konsep yang terdapat pada tabel 1 . dari 32 mahasiswa memperolah nilai rata-rata sebesar 58,09. Menurut Safriya (2006), kategori tingkat kesulitan belajar dari hasil tes tulis yang digunakan dalam penelitian ini adalah sebagai berikut:

Tabel 1. Kategori tingkat kesulitan belajar dari hasil tes tulis

\begin{tabular}{|l|l|l|l|}
\hline $\begin{array}{l}\text { Rentan } \\
\text { g nilai }\end{array}$ & Frekuensi & Persen & Kategori \\
\hline $100-80$ & 5 & $15,62 \%$ & $\begin{array}{l}\text { Sangat } \\
\text { rendah }\end{array}$ \\
\hline $79-60$ & 6 & $18,75 \%$ & Rendah \\
\hline $59-40$ & 8 & $25 \%$ & Sedang \\
\hline $39-20$ & 12 & $37,5 \%$ & Tinggi \\
\hline $19-0$ & 1 & $3,12 \%$ & $\begin{array}{l}\text { Sangat } \\
\text { tinggi }\end{array}$ \\
\hline
\end{tabular}

Tabel 2. Analisis data angket faktor internal penyebab kesulitan belajar mahasiswa

\begin{tabular}{|l|l|l|}
\hline Indikator & Presentasi & Kategori \\
\hline Minat & $87,5 \%$ & $\begin{array}{l}\text { Pengaruh } \\
\text { Sangat lemah }\end{array}$ \\
\hline $\begin{array}{l}\text { Kebiasaan } \\
\text { Belajar }\end{array}$ & $59,37 \%$ & $\begin{array}{l}\text { Cukup } \\
\text { berpengaruh }\end{array}$ \\
\hline Motivasi & $100 \%$ & $\begin{array}{l}\text { Pengaruh } \\
\text { Sangat Lemah }\end{array}$ \\
\hline
\end{tabular}




\begin{tabular}{|l|l|l|}
\hline $\begin{array}{l}\text { Penguasaan } \\
\text { Materi }\end{array}$ & $59,37 \%$ & $\begin{array}{l}\text { Cukup } \\
\text { berpengaruh }\end{array}$ \\
\hline
\end{tabular}

Berdasarkan hasil penelitian menunjukkan bahwa motivasi dalam diri mahasiswa yaitu $100 \%$ serta minat mahasiswa terhadap materi biologi umum sebanyak $87,5 \%$ menunjukkan bahwa tidak mempengaruhi kesulitan belajar mahasiswa. Namun tingginya aspek motivasi dan minat mahasiswa tidak selalu berbanding lurus dengan hasil belajar yang didapat. Selain itu, tingginya motivasi mahasiswa juga tidak serta merta mempengaruhi kesadaran mahasiswa akan pentingnya kualitas kebiasaan belajar secara rutin. Akibatnya siswa mengalami berbagai kesulitan dalam memahami materi yang dipelajari. Sedangkan indikator yang cukup mempengaruhi kesulitan belajar mahasiswa yaitu pada kebiasaan belajar mereka yang tidak mengulang materi di rumah setelah diajarkan di kelas sehingga penguasaan materi mengenai pemahaman konsep sistem pencernaan manusia hanya sebanyak 59,37\%. Berdasarkan hasil penelitian menunjukkan bahwa kebiasaan belajar menjadi salah satu faktor yang paling dominan terhadap timbulnya kesulitan belajar siswa (Ameruddin, 2013). Seseorang yang memiliki jadwal belajar tertentu setiap harinya akan mengalami perbedaan prestasi dengan seseorang yang memiliki jadwal belajar tidak tentu setiap harinya (Subini, 2011).

Tabel 3. Analisis data angket faktor eksternal penyebab kesulitan belajar mahasiswa

\begin{tabular}{|l|l|l|}
\hline Indikator & Presentasi & Kriteria \\
\hline $\begin{array}{l}\text { Perhatian } \\
\text { orang tua }\end{array}$ & $78,12 \%$ & $\begin{array}{l}\text { Pengaruh } \\
\text { Lemah }\end{array}$ \\
\hline $\begin{array}{l}\text { Lingkungan } \\
\text { belajar } \\
\text { (Rumah) }\end{array}$ & $50 \%$ & $\begin{array}{l}\text { Cukup } \\
\text { berpengaruh }\end{array}$ \\
\hline $\begin{array}{l}\text { Alat penunjang } \\
\text { pembelajaran }\end{array}$ & $59,37 \%$ & $\begin{array}{l}\text { Cukup } \\
\text { berpengaruh }\end{array}$ \\
\hline Media belajar & $87,5 \%$ & $\begin{array}{l}\text { Pengaruh } \\
\text { Sangat } \\
\text { Lemah }\end{array}$ \\
\hline Metode belajar & $78,12 \%$ & $\begin{array}{l}\text { Pengaruh } \\
\text { Lemah }\end{array}$ \\
\hline
\end{tabular}

Salah satu Indikator dengan kriteria sangat lemah dalam mempengaruhi kesulitan belajar mahasiswa terdapat pada indikator media belajar yang digunakan di kelas yaitu menggunakan media lcd dan laptop. Menurut mereka media yang digunakan di kelas cukup memadai dan membantu siswa untuk belajar di kelas. Aspek media pembelajaran merupakan indikator yang berpengaruh pada kesulitan belajar mahasiswa. Maka diharapkan media pembelajaran dapat membantu mahasiswa dalam memahami konsep sistem pencernaan pada manusia. Selanjutnya indikator untuk perhatian orang tua di rumah dan metode pembelajaran di kelas berpengaruh lemah terhadap kesulitan belajar mahasiswa dengan presentase sebesar $78,12 \%$. Perhatian orang tua dengan mengingatkan mahasiswa untuk belajar di rumah dapat menjadikan mereka bersemangat dalam belajar karena mendapat dukungan dari orang tua. Apabila orang tua memberikan perhatian lebih kepada putra/putrinya terutama masalah belajar maka dapat meningkatkan prestasi belajar mahasiswa. Sebaliknya, jika mahasiswa tidak mendapatkan perhatian dari orang tua maka mahasiswa cenderung dapat menurunkan prestasi belajarnya di sekolah.

Pada metode pembelajaran di kelas menurut mereka sudah cukup baik yaitu dengan mendengarkan ceramah dari dosen serta interaksi antara mahasiswa dan dosen dengan memberikan tugas presentasi materi setiap minggu sehingga mahasiswa juga aktif dalam mencari informasi materi kuliah. Selain itu beberapa mahasiswa berharap metode pembelajaran ditambah dengan praktek di lapangan sehingga lebih mudah untuk memahami materi.

Indikator yang cukup mempengaruhi kesulitan belajar mahasiswa adalah lingkungan belajar di rumah dan sekitar rumah yaitu sebesar $50 \%$. Lingkungan sosial yang kondusif akan memberikan efek positif terhadap kegiatan belajar sedangkan lingkungan sosial yang kurang kondusif dapat mempengaruhi konsentrasi dan perhatian siswa dalam belajar. Kurangnya konsentrasi seseorang dalam belajar dapat disebabkan oleh berbagai faktor, diantaranya: kurang minat terhadap pelajaran yang dihadapi, gangguan di sekeliling atau ada masalah dengan teman atau keluarga (Salirawati, 2002).

Selain itu faktor penyebab kesulitan belajar adalah kurangnya alat penunjang pembelajaran seperti buku ajar dan video pembelajaran sebayak 59,37\%. Ketidakadanya alat-alat pelajaran secara langsung maupun tidak dapat mempengaruhi keberhasilan belajar siswa. Siswa cenderung berhasil apabila dibantu oleh alat-alat pelajaran yang memadai dan sarana yang baik. Alat pelajaran tersebut dapat menunjang proses pemahaman siswa (Ristiyani dan Bahriah, 2016).

Menurut Subini, alat adalah sesuatu yang dapat digunakan untuk mencapai suatu tujuan 
pengajaran, maka alat tersebut memiliki fungsi sebagai pelengkap dalam upaya untuk mencapai suatu tujuan yang diharapkan. Berdasarkan hasil wawancara, lingkungan belajar di rumah tidak mendukung untuk mengulang materi di kelas atau belajar untuk ujian dengan alasan kondisi lingkungan yang bising dan ramai. Penyebab timbulnya kesulitan belajar mahasiswa adalah tidak adanya dukungan dari lingkungan belajar (Slameto, 2013). Sedangkan untuk membantu mahasiswa dalam memahami materi maka perlu adanya penunjang belajar seperti buku atau video pembelajaran sehingga mahasiswa dapat menguasai sepenuhnya materi sistem pencernaan manusia. Menurut Suardana, buku penunjang belajar merupakan salah satu unsur penting dalam mempengaruhi kesulitan belajar mahasiswa. Buku pelajaran tidak terlepas dari konsep atau materi yang disajikan. Konsep pada buku pelajaran mempengaruhi pola pikir dan pemahaman mahasiswa.

\section{KESIMPULAN}

Berdasarkan hasil penelitian yang telah dilakukan, maka dapat diambil suatu kesimpulan sebagai berikut :

1. Faktor Internal yang menyebabkan kesulitan belajar mahasiswa untuk mata kuliah Biologi Umum materi sistem pencernaan manusia yaitu kebiasaan belajar dan kemampuan penguasaan materi masih kurang yaitu sebanyak $59,37 \%$

2. Faktor Eksternal yang menyebabkan kesulitan belajar mahasiswa untuk mata kuliah Biologi Umum materi sistem pencernaan manusia yaitu Alat penunjang pembelajaran sebanyak $59,37 \%$ dan Kondisi Lingkungan keluarga sebanyak $50 \%$

Hasil penelitian ini kemudian akan dijadikan bahan pengembangan strategi pembelajarannya agar mahasiswa dapat lebih terasah kemampuan berpikirnya serta memberi masukan untuk tindakan lebih lanjut demi mengatasi kesulitan belajar yang tepat sehingga dapat meningkatkan prestasi belajar mereka.

\section{DAFTAR PUSTAKA}

Amerudin., Ariyati, E., dan Nurdini, A. (2013). Deskripsi Kesulitan Belajar dan Faktor Penyebabnya pada Materi Fungi di SMA Islam Bawari Pontianak dan Upaya Perbaikannya. Artikel Penelitian

Lestari, Kurnia, dan Yudhanegara, Muhammad Ridwan. (2015). Penelitian Pendidikan Matematika. Jakarta: PT Refika Aditama Cet. 1.

Marsita, Priatmoko, dan Kusuma. (2013). Analisis kesulitan belajar kimia siswa SMA dalam memahami materi larutan penyangga dengan menggunakan two-tier multiplechoice diagnostic instrument. Jurnal Inovasi Pendidikan Kimia, 4(1): 512-520

Martini, J. (2014). Kesulitan Belajar Perspektif, Asesman, dan Penanggulangannya. Bogor: Ghalia Indonesia.

Riduwan. (2014). Dasar-dasar Statistika. Bandun : Alfabeta.

Ristiyani dan Bahriah. (2016). Analisis Kesulitan Belajar Kimia Siswa di SMAN $X$ Kota Tangerang Selatan. Jurnal Penelitian dan Pembelajaran IPA, 2(1), 18-29.

Safriya, dkk. (2006) Pembelajaran dan Evaluasi Hasil Belajar IPS. Bandung: UPI Press

Salirawati. (2002). Strategi Siwa dalam Mengatasi Kesulitan Belajar. Makalah disampaikan pada kegiatan orientasi siswa baru SLTP N 15 Yogyakarta, tanggal 17 Juli 2002. Tidak diterbitkan.

Slameto. (2013). Belajar dan Faktor-Faktor Yang Mempengaruhinya Jakarta: Rineka Cipta.

Suardana, I Nyoman. (2007). Kesulitan Siswa SMA Memahami Konsep Daur Biogeokimia, Jurnal Ilmiah Guru Kanderang Tingang; 01(01) 46-51.

Subini, N. (2011). Mengatasi Kesulitan Belajar Pada Anak. Jakarta: Perpustakaan Nasional 